\title{
Continuous Process of Reactive Distillation to Produce Bio-additive Triacetin From Glycerol
}

\author{
Zahrul Mufrodi ${ }^{1,2}$, Rochmadi ${ }^{1}$, Sutijan $^{1} \&$ Arief Budiman ${ }^{1}$ \\ ${ }^{1}$ Department of Chemical Chemical Engineering, Gadjah Mada University, Indonesia \\ ${ }^{2}$ Department of Chemical Chemical Engineering, Ahmad Dahlan University, Indonesia \\ Correspondence: Zahrul Mufrodi, Department of Chemical Chemical Engineering, Ahmad Dahlan University, Jl. \\ Prof Soepomo, Janturan, Umbulharjo, Yogyakarta, Indonesia. Tel: 62-821-3886-7525. E-mail: \\ zmufrodi@yahoo.com; Arief Budiman, Department of Chemical Chemical Engineering, Gadjah Mada \\ University, Jl. Grafika 2 Yogyakarta, Indonesia. Tel: 62-816-426-2111. E-mail: abudiman@chemeng.ugm.ac.id
}

Received: August 19, 2013

doi:10.5539/mas.v7n10p70
Accepted: September 19, 2013

Online Published: September 27, 2013

URL: http://dx.doi.org/10.5539/mas.v7n10p70

\begin{abstract}
Glycerol as byproduct of biodiesel production is a very promising low-cost feedstock for producing a wide variety of special and fine chemicals. This great amount of glycerol needs to be converted into higher valuable products. One of glycerol's derivatives potential is triacetin, a good bio-additive as anti-knocking agent. In previous work triacetin synthesis from glycerol and acetic acid using sulfuric acid catalyst has been conducted in batch and continuous process. In this work, triacetin was synthesized using reactive distillation. The continuous process has $98.50 \%$ of glycerol conversion with $8.98 \%$ of triacetin selectivity.
\end{abstract}

Keywords: Glycerol, triacetin, bio-additive, reactive distillation

\section{Introduction}

\subsection{Introduce the Problem}

Glycerol is byproduct of biodiesel process and it is now regarded as a waste product due to tremendous growth of biofuel industry. Stoichiometrically, biodiesel production will generate $10 \%(\mathrm{w} / \mathrm{w})$ glycerol. In other words, every gallon of biodiesel produced generates approximately 1.05 pounds of glycerol. This indicates a 300 -million-gallon-per-year plant will generate about 115,000 tones of 99.9 percent pure glycerin. However, this great amount of glycerol can be utilized as raw material to produce several high value chemicals such as monoacetin, diacetin and triacetin by acetylation process as shown in Equations 1 through 3.<smiles>CC(=O)OCC(O)COC(C)=O</smiles> 
<smiles>CC(=O)OCC(O)CO</smiles>

Monoacetin<smiles>CC(=O)O</smiles><smiles>CC(=O)OCC(CO)OC(C)=O</smiles>

Diacetin

Acetic acid<smiles>CC(=O)O</smiles><smiles>CC(=O)OCC(COC(C)=O)OC(C)=O</smiles>

Diacetin

Acetic acid

Triacetin

Water

There are several industrial synthesis alternatives for utilization of glycerol, one of them is acetylation process of glycerol and acetic acid. The products of this process has great industrial applications, such as triacetin has been used for pharmaceutical and cosmetics industry, while monoacetin and diacetin have been applied in cryogenic industry and used as raw material for biodegradable polyesters manufacture (Galan et al., 2009; Reddy et al., 2010; Rahmat et al., 2010). Besides, triacetin is a promising alternative chemical to be transformed into fuel additive (Rao \& Rao, 2011; Ferreira et al., 2009; Hou et al., 1998). Mixing 10\% (w/w) of triacetin to biodiesel can give better performance as compared to the pure biodiesel (Zang \& Yuan, 2001).

\subsection{Catalyst for Reaction}

Traditionally, the reaction of glycerol and acetic acid is carried out using homogeneous catalysts, such as sulphuric acid (Gelosa et al., 2003; Mufrodi et al., 2010; Mufrodi et al., 2012) and acidic functional ionic liquid (Li et al., 2009), $\mathrm{H}_{3} \mathrm{PO}_{4}, \mathrm{HCl}, \mathrm{HNO}_{3}$ and $\mathrm{H}_{2} \mathrm{SO}_{4}$ (Khayoon \& Hameed, 2011). This process has advantages including high activity (complete conversion within short time) and mild reaction conditions (from 100 to $120{ }^{\circ} \mathrm{C}$ and atmospheric pressure). However, researchers have started to study heterogeneous catalyst for this reaction, due to its advantages.

Several heterogeneous solid catalysts for synthesis of triacetin from glycerol and acetic acid has been explored, such as aminosulphonate (Liu et al., 2007), phosphotungstic, mesoporous silica with sulfonic acid groups (Melero et al., 2007), $\mathrm{SO}_{4}{ }^{2-} / \mathrm{ZrO}^{2-} \mathrm{TiO}_{2}$ (Wu et al., 2007), Amberlist-15 15 (Zhou et al., 2013), K-10, Niobic acid, HZMS-5 and HUSY (Goncalves et al., 2008), Amberlyst-35 (Liao et al., 2010), $\mathrm{ZrO}_{2}, \mathrm{TiO}_{2}-\mathrm{ZrO}_{2}$, $\mathrm{WOx} / \mathrm{TiO}_{2}-\mathrm{ZrO}_{2}$ and $\mathrm{MoOx} / \mathrm{TiO}_{2}-\mathrm{ZrO}_{2}$ (Reddy et al., 2010). However, heterogeneous catalyst has complicated catalytically sites, i.e., chemically and geometrically for improving selectivity to a certain product.

So far, homogeneous catalysis is widely used over heterogeneous in industry for the following reasons:

a. Access to the reagents for homogeneous catalyst is easier since it is in solution, so there is improved activity and milder reaction conditions can be used.

b. The heat transfer in homogeneous phase for highly exothermic or endothermic reactions is not a problem.

c. Mechanisms are better understood.

\subsection{Continuous Process}

Current triacetin productions are mostly using batch-tank reactor. For a small capacity, batch system is very versatile, but for mass production, this process is tedious, labor intensive and low in productivity. However, 
continuous acetylation processes are preferred over batch processes in commercial production. The basic advantages of continuous-flow process are a greater productivity and a consistent product quality.

Continuous acetylation of glycerol was studied as early as the 196s by Morrissette (1964). In this system, synthesis of triacetin from glycerol was conducted in continuous process by a fixed bed reactor at the temperature of $323 \mathrm{~K}$ with Amberlyst catalyst. The best result was obtained on ratio of acetic acid to glycerol of $3: 1$. Then, recently Fukumura et al. (2009) improved the process by using Amberlyst-15 in catalytic column. By the ratio of glycerol to acetic acid was 2:9 and flow rate was $0.3 \mathrm{~cm}^{3} /$ minute, the acetic acid conversion obtained in this process was $50 \%$.

\section{Method}

\subsection{Materials and Dimension of Reactive Distillation Column}

The materials used in this experiment are glycerol of $93 \%$ purity (production of P \& G Chemicals), acetic acid of 98\% purity (production of Petrochemical Chang Cun) and sulfuric acid as catalyst (Merck Index No. 016-020-00-8).

Reactive distillation (RD) column with dimensions of height as $1.20 \mathrm{~m}$, diameter as $45 \mathrm{~mm}$ and the wall thickness as $2 \mathrm{~mm}$. The column contains glass raschig rings with dimensions out diameter as $0.5 \mathrm{~mm}$, length as $8.5 \mathrm{~mm}$ and wall thickness as $0.85 \mathrm{~mm}$. The column was insulated to reduce heat loss and equipped with total condenser and partial reboiler. Figure 1 shows the schematic of a reactive distillation for triacetin production. Acetic acid and glycerol was fed to $F_{2}$ and $F_{1}$. The column was operated at atmospheric pressure. The temperature of acetic acid feed streams was $391 \mathrm{~K}$ and glycerol feed streams was $373 \mathrm{~K}$.

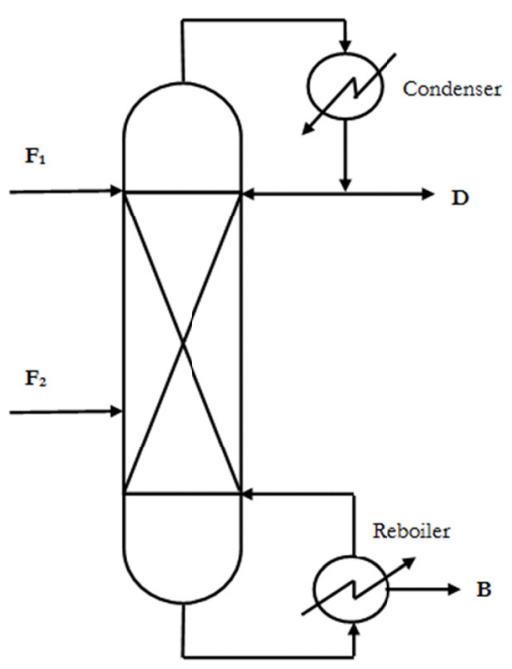

Figure 1. Reactive distillation (RD) column

\subsection{Sampling Procedures}

Experiment begun by heating glycerol and acetic acid feed. Glycerol (F1) entered from the top of the column and acetic acid (F2) on 2/3 height of the upper part of the column. Glycerol and acetic acid discharged in accordance with the variation of the velocity which would be observed. Residual acetic acid and water would rise to the top of the column and then flowed through the total condenser. Product stream exiting the top divided into distillate (D) taken as a result and certain amount returned to the column as reflux. The bottom product stream used a partial reboiler where the vapour raised in the reboiler was re-introduced into the unit at the bottom of the column and liquid removed from the reboiler was taken as the bottoms (B). This B product contains monoacetin, diacetin, triacetin, sulfuric acid catalyst and small amount of acetic acid and glycerol. Then, after reaching the steady operating conditions, samples at various specified were taken and analysis with gas chromatograph.

\subsection{Samples Analysis}

Gas chromatograph (GC) was used for the analysis since it was proved to provide good results in monoacetin, diacetin and triacetin analysis (Morrissette \& Link, 1964; Ogawa et al., 1988; Lu, 1991; Uematsu et al., 1997). 
GC analyses were performed using an Agilent 6890N MSD 5975B with the specification of HP-5ms column 5\% Phenyl methyl siloxane, Model Number: Agilent 19091S-433, the injector temperature of 548 K, the temperature at the detector: MS Quad was $523 \mathrm{~K}$, injection volume of 1 micro liter, injector pressure of 3.27 psi. Materials GC standard are triacetin of 99\% purity from Kanto Chemical Co. Inc. (Cat. No. 40224-30), diacetin of 97\% purity from Kanto Chemical Co. Inc. (Cat. No. 10018-32) and monoacetin of 99\% purity from Kanto Chemical Co. Inc. (Cat. No. 25371-32) and glycerol more than 99\% purity from Waco Pure Chemical Industries Ltd. (Reff. No. 079-00614).

\section{Results and Discussion}

\subsection{Effect of Packing Height}

The height of column is responsible for contact time between glycerol and acetic acid in reaction zone of RD column. That's why knowledge of the packing height is essential for design of RD column to get the best optimizing performance of packing. The effect of the packing height to the concentration of monoacetin, diacetin and triacetin are shown in Figure 2. It shows that the increase of the height of packing would increase the concentration of the diacetin and triacetin. But the monoacetin concentration was decreased. It means that monoacetin was converted into diacetin and triacetin due to excessive contact time because of the height of column. The larger the contact area leads to the better reaction. Increasing of packing height as $19.5 \mathrm{~cm}$ would cause an increase diacetin and triacetin of 3.81 and $4.95 \%$ while monoacetin decrease of $3.39 \%$.

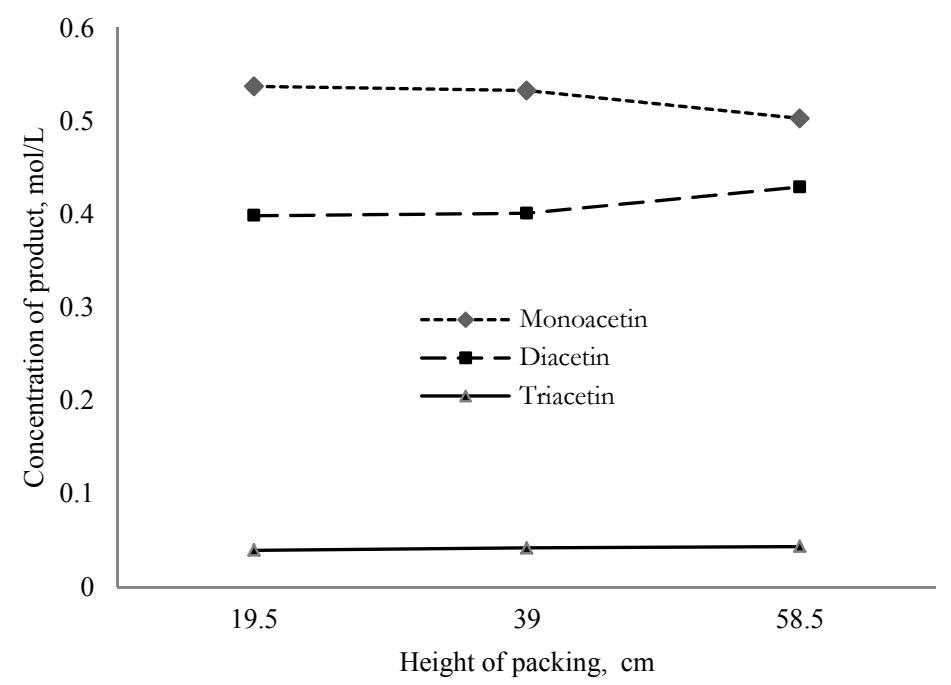

Figure 2. Concentration monoacetin, diacetin and triacetin as function of height of packing

Glycerol conversion increased linearly with the packing height. The effect of packing height on the glycerol conversion is shown in Figure 3. The effect of packing height resulted in an increase concentration of triacetin as product. Triacetin conversion was increased as $0.0077 \%$ at $19.5 \mathrm{~cm}$ interval of packing height. Maximum conversion of glycerol in this process was $97.50 \%$. 


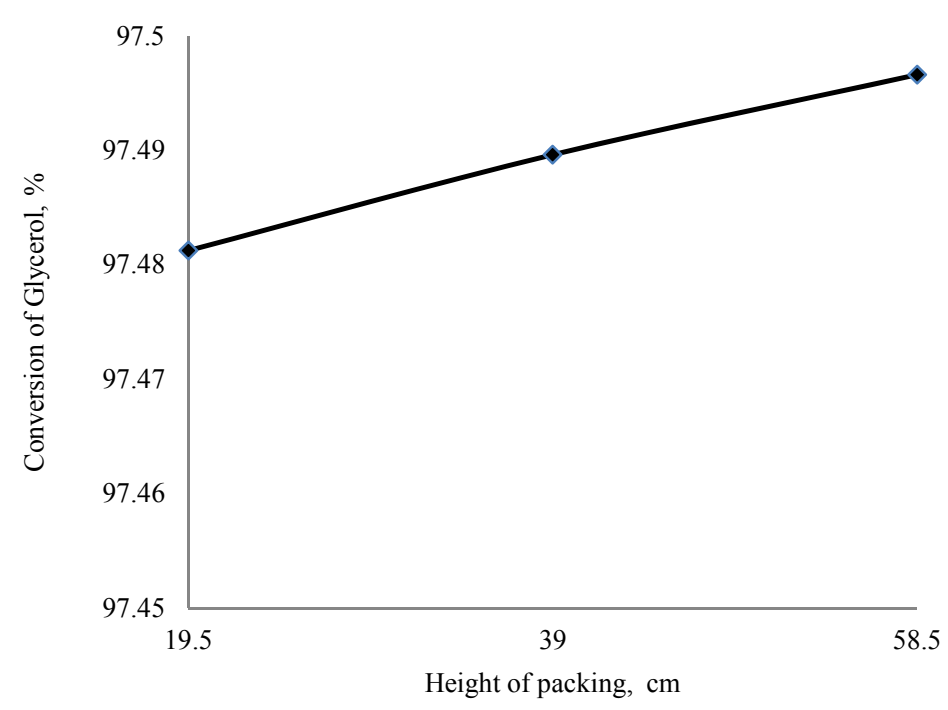

Figure 3. Conversion of glycerol as function of height of packing

\subsection{Effect of Acetic Acid to Glycerol Mole Ratio}

One common way to increase the reaction rate is using the excess amount of one of the reactants. Based on the stoichiometric calculation, 3 moles of acetic acid requires one mole glycerol to produce one mole of triacetin. In these experiments, the molar ratios of acetic acid to glycerol were varied 3, 4, 5 and 6. Le Chatelier's principle stated that if a system in chemical equilibrium changes (concentration, temperature, volume or partial pressure), it will cause the equilibrium shifts to counteract the change. Consequently, the new equilibrium will be established. Changes in the concentration of reactant will shift the equilibrium to the side reactions that reduce the concentration. This case means the addition of one of the reactants will result in a shift towards product formation. Here, effect of ratio mol acetic acid to mol glycerol resulted in an increase concentration of triacetin as product. Increasing of one mole ratio of acetic acid to glycerol would cause an increase triacetin of $28.06 \%$.

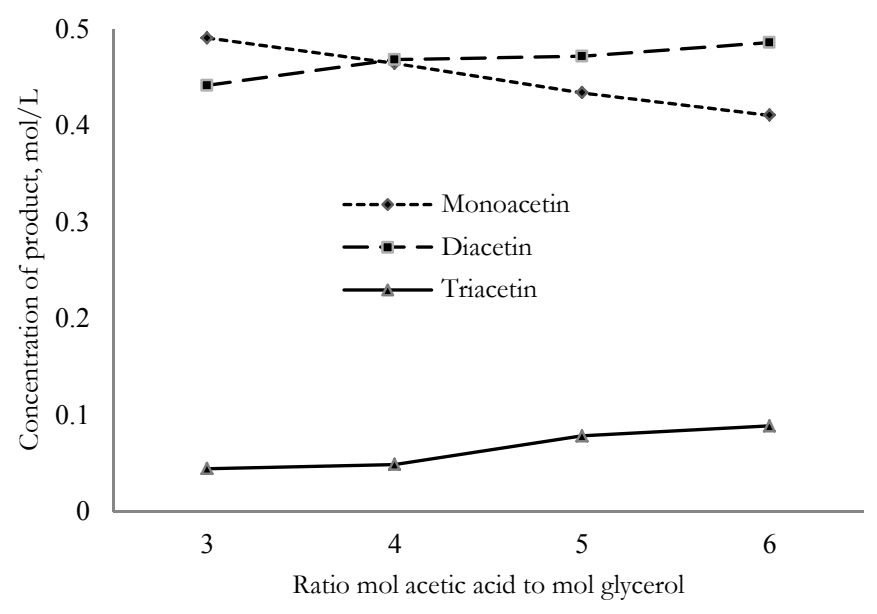

Figure 4. Concentration monoacetin, diacetin and triacetin from bottom product as function of ratio mol acetic acid to mol glycerol

The effect of ratio mol acetic acid to mol glycerol on the glycerol conversion is shown in Figure 5. Triacetin conversion was increased by $0.2941 \%$ at $1 \mathrm{~mol}$ acetic acid addition. In this process, the maximum conversion of glycerol obtained was $98.51 \%$. It was higher than glycerol conversion using the same catalyst in batch reactor that was $96.30 \%$ (Mufrodi et al., 2012). 


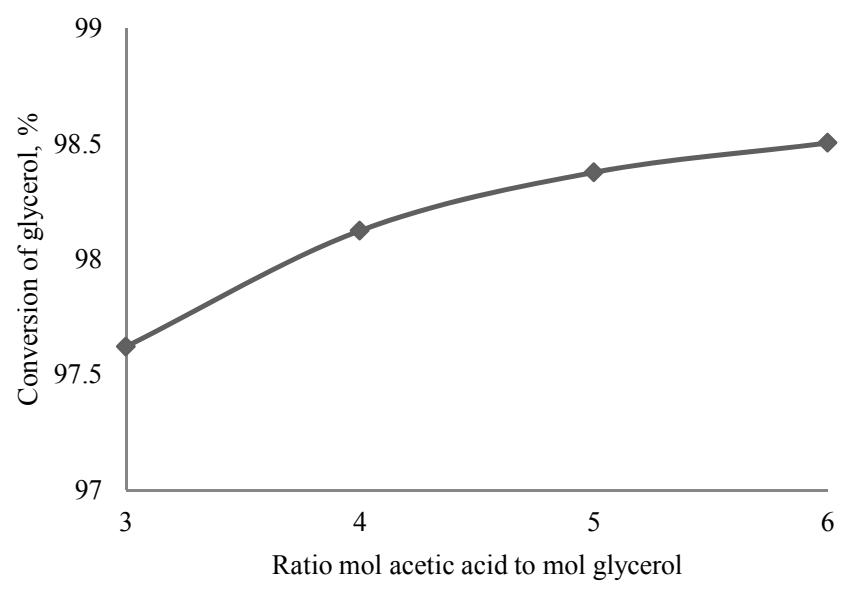

Figure 5. Conversion of glycerol as function of ratio mol acetic acid to mol glycerol

\subsection{Effect of Reflux Ratio (R)}

Reflux is an important part in the process of distillation. In this work, reactive distillation's vapor at the top of the column output is condensed in the total condenser. Then the condenser discharge flow partly as distillate and returned to the RD column as reflux. Reflux ratio is the ratio between the amounts of fluid that is returned in the column compared with the distillate. Increase the reflux ratio can be generated by adding heat to the reboiler. Effect of reflux ratio also affects the results obtained. Figure 6 shows that the increase in reflux ratio of 0.1 would increased diacetin and triacetin as $1.162 \%$ and $1.2 \%$ while monoacetin decreased as $2.085 \%$.

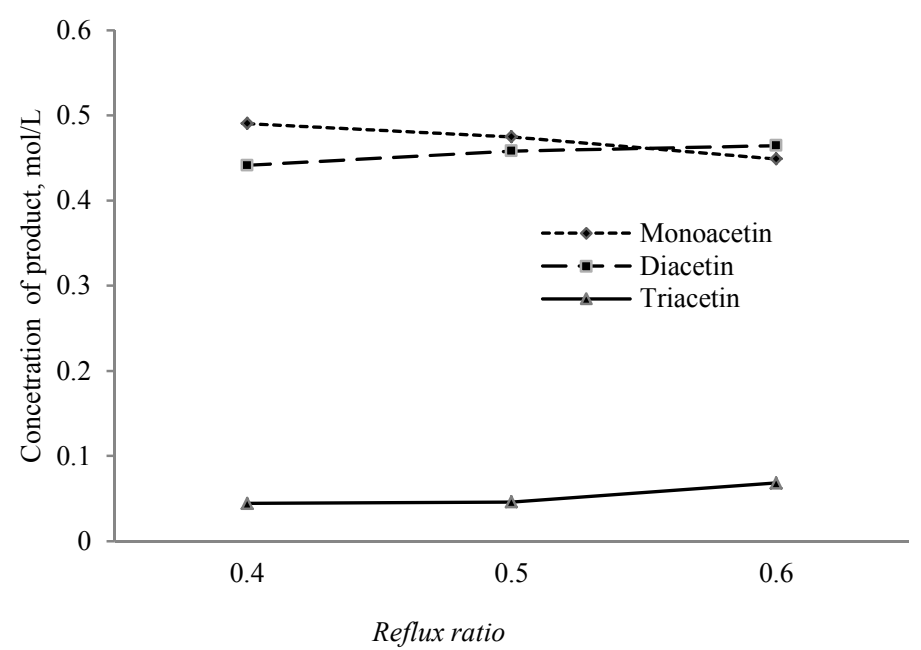

Figure 6. Concentration monoacetin, diacetin and triacetin from bottom product as function of reflux ratio

The higher reflux ratio, $\mathrm{R}$ would lead to greater contact time between the reactants, resulting in the better product. The increasing of reflux ratio would increase the conversion of glycerol on the results. The average increasing of reflux ratio of 0.1 causes the increasing in conversions as $0.27747 \%$ (see Figure 7 ). 


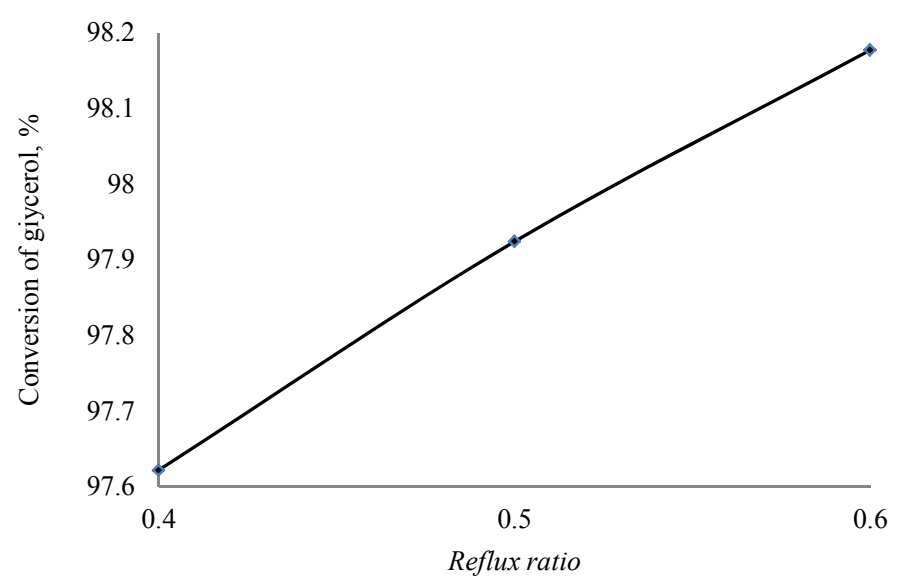

Figure 7. Conversion of glycerol as function of reflux ratio

Table 1 shows the effect of variables to selectivity of monoacetin, diacetin and triacetin using continuous process of reactive distillation. The most affecting variable to the selectivity was the mole ratio of acetic acid to glycerol. The less affecting variable was the packing height.

Table 1. The effect of packing height, mol ratio of acetic acid to glycerol and reflux ratio

\begin{tabular}{lcccc}
\hline \multicolumn{1}{c}{ Variables } & \multicolumn{3}{c}{ Selectivity, \% } \\
& & Monoacetin & Diacetin & Triacetin \\
\hline Height of & 19.5 & 55.090 & 40.868 & 4.042 \\
packing, cm & 39.0 & 54.619 & 41.105 & 4.276 \\
& 58.5 & 51.557 & 43.992 & 4.451 \\
\hline \multirow{2}{*}{ Mol ratio of } & 3 & 50.2622 & 45.2166 & 4.5212 \\
acetic acid to & 4 & 47.3289 & 47.7309 & 4.9402 \\
glycerol & 5 & 44.1129 & 47.9439 & 7.9431 \\
& 6 & 41.6773 & 49.3450 & 8.9777 \\
\hline \multirow{2}{*}{ Reflux ratio } & 0.4 & 49.8031 & 44.1414 & 4.4137 \\
& 0.6 & 49.0219 & 45.8355 & 4.5875 \\
& 47.2429 & 46.4658 & 6.8142 \\
\hline
\end{tabular}

This paper only uses three groups' tests for each variable. The next paper will discuss about reactive distillation simulation with expand the range of variables i.e. height of packing, mol ratio of acetic acid to glycerol and reflux ratio. The aim of simulation is to get the maximum selectivity of triacetin.

\section{Conclusion}

This paper studies acetylation of glycerol in continuous reactive column. The results show that acetylation by reactive column can be used to increase the conversion of glycerol and selectivity to triacetin. Adding acetic acid, increasing height of packing and reflux ratio resulted in an increase of triacetin selectivity.

\section{Acknowledgements}

The authors would like to acknowledge the Ministry of Agriculture Indonesia through KKP3T project no. 1151/LB.620/I.1/3/2012 and the scholarship of doctorate program (BPPS) at Gadjah Mada University from National Education of Indonesia. 


\section{References}

Balaraju, M., Nikhitha, P., Jagadeeswaraiah, K., Srilatha, K., Prasad, P. S. S., \& Lingaiah, N. (2010). Acetylation of glycerol to synthesize bioadditives over niobic acid supported tungstophosphoric acid catalysts. Fuel Process. Tech., 91, 249-253. http://dx.doi.org/10.1016/j.fuproc.2009.10.005

Bonet, J. Costa, J., Sire, R., Reneaume, J. M., Plesu, E. A., Plesu, V., \& Bozga, G., (2009). Revalorization of glycerol: Comestible oil from biodiesel synthesis. Food and Bioproducts Process, 87, 171-178. http://dx.doi.org/10.1016/j.fbp.2009.06.003

Ferreira, P., Fonseca, I. M., Ramos, A. M., Vital, J., \& Castanheiro, J. E., (2009). Esterification of Glycerol with acetic acid over dodecamolybdophosphoric acid encaged in USY Zeolite. Catal Commun., 10, 481-484. http://dx.doi.org/10.1016/j.catcom.2008.10.015

Ferreira, P., Fonseca, I. M., Ramos, A. M., Vital, J., \& Castanheiro, J. E. (2011). Acetylation of glycerol over heteropolyacids supported on activated carbon. Catal Commun., 12, 573-576. http://dx.doi.org/10.1016/j.catcom.2010.11.022

Fukumura, T., Toda, T., Seki, Y., Kubo, M., Kitakawa, N. S., \& Yonemoto, T. (2009). Catalytic Synthesis of Glycerol Monoacetate Using a Continuous Expanded Bed Column Reactor Packed with Cation-Exchange Resin. Ind. Eng. Chem. Res., 48, 1816-1823. http://dx.doi.org/10.1021/ie800625g

Galan, M. I., Bonet, J., Sire, R., Reneaume, J. M., \& Plesu, A. E., (2009). From Residual to Use Oil: Revalorization of Glycerine from the Biodisel Synthesis. Bioresource Tech., 100, 3775-3778. http://dx.doi.org/10.1016/j.biortech.2009.01.066

Gelosa, D., Ramaioli, M., Valente, G., \& Morbidelli, M. (2003). Chromatographic Reactors: Esterification of Glycerol with Acetic Acid Using Acidic Polymeric Resins. Ind. Eng. Chem. Res., 42, 6536-6544. http://dx.doi.org/10.1021/ie030292n

Goncalves, V. L. C., Pinto, B. P., Silva, J. C., \& Mota, C. J. A. (2008). Acetylation of glycerol catalyzed by different solid acids, Catal. Today, 133-135, 673-677. http://dx.doi.org/10.1016/j.cattod.2007.12.037

Hou, J., Zhang, Q., Shi, W., \& Li, Y. (1998). New Process for synthesis of Triacetin. Henan Huagon, 15, 18-19.

Khayoon, M. S., \& Hameed, B. H. (2011). Acetylation of glycerol to biofuel additives over sulfated activated carbon catalyst. Bioresour Tech., 102, 9229-9235. http://dx.doi.org/10.1016/j.biortech.2011.07.035

Li, L., Yua, S. T., Xie, C. X., Liua, F. S., \& Li, H. J. (2009). Synthesis of glycerol triacetate using functionalized ionic liquid as catalyst. J Chem Technol Biotechnol, 84, 1649-1652. http://dx.doi.org/10.1002/jctb.2223

Liao, X., Zhu, Y., Wanga, S. G., Chen, H., \& Li, Y. (2010). Theoretical elucidation of acetylating glycerol with acetic acid and acetic anhydride. Appl. Catal. B: Environ., 94, 64-70. http://dx.doi.org/10.1016/j.fuproc.2009.03.015

Liu, H., Lu, Y., \& Gong, S. (2007). Study on Synthesis of Glycerol Triacetate using Acidic Fungtional Ionic Liquid as Catalyst. Hebei Gongye Keji, 24(1), 21-23.

Lu, Y. (1991). Determination of triacetin by gas chromatography. Fenxi Ceshi Tongbao, 10(5), 77-79.

Melero, J. A., Grieken, R. V., Morales, G., \& Paniagua, M. (2007). Acidic Mesoporous Silica for the Acetylation of Glycerol: Synthesis of Bioadditives to Petrol Fuel. Energy and Fuels, 21, 1782-1791. http://dx.doi.org/10.1021/ef060647q

Morrissette, R. A., \& Link, W. E. (1964). Gas-Liquid Cromatography of Polar Fatty Derivatives. JAOCS, 41(2), 415-418.

Mufrodi, Z., Rochmadi, Sutijan, \& Budiman, A. (2010). Effects of Temperature and Catalyst upon Triacetin Production from Glycerol (by-Product Biodiesel Production) as Octane Booster. Proc. Advances in Renewable Energy Technologies Int. Conf., Cyberjaya, Malaysia, pp. 130-134.

Mufrodi, Z., Rochmadi, Sutijan, \& Budiman, A. (2012). Chemical Kinetics for Synthesis of Triacetin from Biodiesel Byproduct. Int. J. Chem., 4(2), 100-107. http://dx.doi.org/10.5539/ijc.v4n2p101

Ogawa, T., Fujii, R., \& Tanaka, K. (1988). A method for determination of triacetin in foods by gas chromatography. J. Food Hyg. Soc. Jpn., 29, 180-184. http://dx.doi.org/10.3358/shokueishi.29.180

Rahmat, N., Abdullah, A. Z., \& Mohamed, A. R. (2010). Recent progress on innovative and potential technologies for glycerol transformation into fuel additives: A critical review. Renewable and Sustainable Energy Reviews, 14, 987-1000. http://dx.doi.org/10.1016/j.rser.2009.11.010 
Rao, P. V., \& Rao, B. V. A. (2011). Effect of adding Triacetin additive with Coconut oil methyl ester (COME) in performance and emission characteristics of DI diesel engine. Int. J. of Thermal Tech., 1, 100-106.

Reddy, P. S., Sudarsanam, P., Raju, G., \& Reddy, B. M. (2010). Synthesis of bio-additives: Acetylation of glycerol over zirconia-based solid acid catalysts. Catal Commun, 11, 1224-1228. http://dx.doi.org/10.1016/j.catcom.2010.07.006

Reddy, P. S., Sudarsanam, P., Raju, G., \& Reddy, B. M. (2012). Selective acetylation of glycerol over $\mathrm{CeO}_{2}-\mathrm{M}$ and $\mathrm{SO}_{4}{ }^{2}-/ \mathrm{CeO}_{2}-\mathrm{M}\left(\mathrm{M}=\mathrm{ZrO}_{2}\right.$ and $\left.\mathrm{Al}_{2} \mathrm{O}_{3}\right)$ catalysts for synthesis of bioadditives. J. Ind. \& Eng. Chem., 18, 648-654. http://dx.doi.org/10.1016/j.jiec.2011.11.063

Rodríguez, I. D., \& Gaigneaux, E. M. (2012). Glycerol acetylation catalysed by ion exchange resins. Catal. Today, 195, 14-21. http://dx.doi.org/10.1016/j.cattod.2012.04.031

Testa, M. L., Parola, V. L., Liotta, L. F., \& Venezia, A. M. (2013). Screening of different solid acid catalysts for glycerol acetylation. J. Molec. Catal. A: Chemical, 367, 69-76, http://dx.doi.org/10.1016/j.molcata.2012.10.027

Uematsu, Y., Sadamasu, Y., \& Hirata, K. (1997). Determination of carrier solvents in flavor preparations by GC and GC/MS. J. Food Hyg. Soc. Jpn., 38, 452-459. http://dx.doi.org/10.3358/shokueishi.38.6_452

Wu, H., Yu, B., \& Ge, S. (2007). Complex Solid Super Acid $\mathrm{SO}_{4}{ }^{2-} / \mathrm{ZrO}^{2-} \mathrm{TiO}_{2}$ used in Synthesis of Glycerol Triacetate. Huagon jinzhan, 26(7), 1041-1043.

Zang, M., \& Yuan, X. (2001). Synthesis of Glycerol Triacetate Catalized by Phosphotungstic Acid. Hecheng Hиахие, 9(5), 469-472. http://dx.doi.org/10.1002/jctb.2223

Zhou, L., Nguyen, T. H., \& Adesina, A. A. (2012). The acetylation of glycerol over amberlyst-15: Kinetic and product distribution. Fuel Process. Tech., 104, 310-318. http://dx.doi.org/10.1016/j.fuproc.2012.06.001

Zhou, L., Zaini, E. A., \& Adesina, A. A. (2013). Catalytic characteristics and parameters optimization of the glycerol acetylation over solid acid catalysts. Fuel, 103, 617-625. http://dx.doi.org/10.1016/j.fuel.2012.05.042

\section{Copyrights}

Copyright for this article is retained by the author(s), with first publication rights granted to the journal.

This is an open-access article distributed under the terms and conditions of the Creative Commons Attribution license (http://creativecommons.org/licenses/by/3.0/). 